Monika Marczuk

\title{
OKO UŚWIĘCONE. \\ O PEWNEJ IDÉE FIXE MYŚLI FRANCUSKIEJ PIERWSZEJ POLOWY XX WIEKU
}

\section{WSTĘPNY RZUT OKA}

Pani Bovary truje się arszenikiem, by wnet przeżyć ostatnie męki swojego życia. Leży nieruchomo, z przewróconymi oczami, otwartymi ustami, w ostatnich minutach niezdolna nawet do odczuwania bólu, wcześniej palącego jej ciało. Słysząc dochodzący zza okna śpiew ślepca, Emma zrywa się niczym rażona prądem i „z okiem nieruchomym, rozwartym” zaczyna się śmiać bezmyślnie, potwornie, złowieszczo. Po chwili umiera.

Scena śmierci Emmy Bovary z pewnością niejednemu czytelnikowi nie dawała spokoju, a podobnie jest bodajże z czytelnikami Historii oka Georgesa Bataille'a. Można powiedzieć, że jest ona, owa Historia oka, wariacją na temat tego właśnie fragmentu powieści Gustawa Flauberta. Fascynacja okiem, śmiechem i śmiercią łączy obu pisarzy. Oto więc oko, jedno oko, wywrócone, otwarte, zamglone; wyłupione oko niewidomego, który nie tylko nie widzi, ale który przez to właśnie widzi więcej, a już na pewno widzi inaczej i co innego. Oraz śmiech, nieprzyzwoity i niczym nie powodowany, pochodzący jak gdyby z innego świata, burzący trzeźwą myśl nagłym uczuciem grozy, jaką niesie śmierć. Wszystko to zajmowało Bataille'a, tak jak wcześniej Flauberta.

Przedmiot, który pragnę wziąć tu na warsztat - oko - sam w sobie może nie wydawać się wyjątkowy, lecz z całą pewnością stał się taki dla francuskich intelektualistów począwszy od pierwszej połowy XX wieku. Może to 
wydać się dziwne - dlaczegóż to oko z czegoś obojętnego staje się nagle przedmiotem niemalże sakralnym, by nie powiedzieć fetyszem. Historia myśli zachodniej, przede wszystkim zaś francuskiej, jak twierdzi Martin Jay, wyniosła do najwyższej godności władzę wzroku, wyniosła widzenie ponad inne zmysły, a tym samym zachowała i umocniła antyczny podział na zmysły wyższe i niższe. To właśnie oko, mimo ograniczonych możliwości, zdobyło uznanie - nawet wśród filozofów sławnych ze swojego sceptycyzmu i odegrało decydującą rolę w kształtowaniu się myśli zachodniej. Jay stawia również tezę, że cała filozofia francuska, aż do początku dwudziestego wie$\mathrm{ku}$, najpierw oczarowana kilkoma wizualnymi metaforami (zaczerpniętymi od Platona, św. Augustyna, Kartezjusza), później zaś oświeceniową ufnością w prawdziwość danych przekazywanych za pomocą zmysłów, fundowała swój gmach na wizualnych przedstawieniach. Takie skoncentrowanie się myśli na obrazowych wizjach amerykański badacz określa mianem wzrokocentryzmu lub okulocentryzmu. Dyskurs, który takiemu okulocentryzmowi się sprzeciwia i poszukuje alternatywnych rozwiązań, nazywa Jay dyskursem antyokulocentrycznym, odczarowującym oko. A za najdoskonalszego jego wyraziciela uznaje Bataille'a.

W owym interesującym nas półwieczu, a więc w pierwszej połowie XX wieku, znaleźć można pewną grupę ludzi pióra (bo mowa nie tylko i nie przede wszystkim o filozofiach, lecz także antropologach, etnografach, teoretykach literatury czy też samych literatach), którzy temat oka wielokrotnie podejmowali. W tekście tym w sposób skrótowy omówię obecną w twórczości Georgesa Bataille’a, Michela Leirisa oraz Maurice'a Blanchota fascynację okiem. (Należałoby dodać jeszcze, że temat ten nieobcy był również Pierre'owi Klossowskiemu czy Rogerowi Caillois). Jeden i ten sam obiekt - oko - zajmuje miejsce centralne, jakkolwiek, nomen omen, oglądany z odmiennych perspektyw. Każdy z powstałych opisów wyraźnie różni się od pozostałych, lecz mimo to występuje między nimi uderzające wprost podobieństwo. Choć nie zawsze w sposób uświadomiony, niemniej jednak rzeczywisty, autorzy ci kierowali ostrze swojej krytyki przeciwko dominującej roli spojrzenia we wszystkich niemal dziedzinach życia. Fikcyjne wybijanie, oślepianie, wyłupywanie oka to nic innego jak zamaskowana walka wytoczona wzrokocentryzmowi. 


\section{2. Око (L'OEIL) I JAJKo (L'OEUF) - GEORGES BATAILLE}

W roku 1928 pod pseudonimem „Lord Auch” zostaje opublikowane opowiadanie Historia oka. Przedstawia ono perypetie trójki szesnastolatków narratora oraz dwóch jego przyjaciółek, Simony oraz Marceli. Czyny, jakich wspólnie dopuszczają się przede wszystkim główny bohater i Simona (Marcela pełni najczęściej rolę obiektu pożądania, ostatecznie popełnia samobójstwo, lecz i tak jest zwornikiem spajającym akcję), niecodzienne i co najmniej zaskakujące, prowadzą do finału równie tajemniczego, jak całe opowiadanie. Spośród wielu obrazów w Historii oka, da się wyróżnić przede wszystkim trzy najbardziej znaczące. Pierwszym jest nocna wizja trzepoczącego na wietrze prześcieradła, przez którego mokrą plamę prześwieca blask księżyca. Drugim widowiskowa korrida - podczas jednej z walk ginie od rany zadanej w oko matador Granero. Oraz trzeci obraz - scena w sewilskim kościele, gdzie dwoje głównych bohaterów wraz z ich angielskim przyjacielem dopuszcza się gwałtu na księdzu oraz bezcześci ciało i krew Pańską. Te dwie ostatnie sceny przedstawiają ponadto akt wyjmowania oka (bardziej bądź mniej gwałtowny), który co prawda okalecza ciało, lecz samemu oku przyznaje autonomię. Ważne jest to, że „kastracji” ulega tylko jedno prawe. Oczy są dla Bataille'a przedmiotem sacrum. Podział na sacrum prawe i sacrum lewe (Durkheim) odnosi się również do nich. Prawe oko skupia cechy falliczne, czyli męskie, takie jak rozum, siła, dostojność, i właśnie za sprawą tego, staje się ono obiektem szczególnej nienawiści - nieustannie gnębione, nieprzerwanie poddawane torturom. Inaczej z okiem lewym, kojarzonym z siłami nieczystymi, zepsuciem, nieładem, które zyskuje szczególny status. Symboliczna kastracja prawego oka - jak zdaje się twierdzić Bataille - czyli zmiana paradygmatu myślenia z logocentrycznego (albo za Irigaray - fallogocentrycznego) - zapewnić może swobodny ruch myśli, lecz nie to tylko - obiecuje dopełnić myśl, doprowadzić ją do końca.

W opowiadaniu daje się zauważyć podobieństwo między pewnymi przedmiotami, które w nim się kolejno się przewijają. Chodzi tu przede wszystkim o trzy, a nawet cztery takie przedmioty: oko, jajko, zwierzęce jądra oraz miskę z mlekiem, która - gdy spojrzeć na nią z góry - również kształtem i barwą przywodzi na myśl gałkę oczną lub obrane jajko. Należy zadać pytanie, skąd ta niepodobna do niczego fascynacja i związane z nią fantazje? Najwięcej w tej kwestii ma do powiedzenia oczywiście sama 
Historia oka, jednak nie można w niej odnaleźć żadnej przyczyny, dla której autor często tak zwraca uwagę na oko, jajko czy jądra. W Reminiscencjach, które są dodatkiem do dzieła, Bataille wyjaśnia bez ogródek:

Moim ojcem był syfilityk (tabetyk). Oślepł (był już ślepy, gdy mnie począł), a kiedy miałem dwa czy cztery lata, choroba sparaliżowała go. [...] paraliż i ślepota miały takie oto konsekwencje: nie mógł, jak my, odlewać się w ubikacji, sikał w fotelu, miał do tego specjalny zbiornik. Sikał przy mnie pod kocykiem, którym, jako że ślepy, nie przykrywał się najlepiej. Najbardziej przykry zresztą był sposób, w jaki patrzył. Jego nic nie widzące źrenice tonęły w mroku, gubily się pod powiekami - ten ruch powstawał zwykle w chwili popuszczania. Miał bardzo szeroko otwarte oczy w wychudłej twarzy, wyciosanej jak orli dziób. W zasadzie, kiedy oddawał mocz, jego oczy stawały się prawie białe: sprawiały wówczas obłędne wrażenie - jego wzrok miał za przedmiot świat, który tylko on mógł dojrzeć, a ta wizja przyprawiała go o roztargniony uśmiech. Ten właśnie obraz białych oczu łączę z obrazem jajek; kiedy mówię o oku bądź jajkach, zazwyczaj pojawia się uryna ${ }^{1}$.

Wyznanie to było zapewne rezultatem udziału w sesjach psychoanalitycznych, które Bataille odbywał w tamtym czasie. I chociaż zacytowany fragment nie pozostawia wątpliwości co do pochodzenia Bataille'owskiego urzeczenia okiem, nie należy zapominać i o tym, że psychoanaliza w ówczesnej Francji stawia dopiero pierwsze kroki.

Niemożliwość dotarcia do doświadczeń, jakie były udziałem ojca, oraz świadectwa ich niezwykłego charakteru - nieostrość spojrzenia oraz odruchowy uśmiech (przypominający spazmatyczny śmiech Emmy Bovary) pozwalają wyprowadzić wniosek, że jedynym określeniem w dużej mierze odpowiadającym temu wspomnieniu jest sacrum. Miałożby ono być tym, co zawsze uchyla się przed ostatecznym wyjaśnieniem, mimo podejmowanych po wielekroć prób sprostania temu zadaniu? Oko w twórczości Bataille'a nigdy nie jest tylko organem, który umożliwia widzenie. Wolno nawet powiedzieć, że tym jest ono w najmniejszym stopniu. Niewidome oczy ojca, które niekiedy zdawały się wskazywać na jego duchową nieobecność, oczy otwarte i wypełnione pustką, budziły przerażenie, umacniając najbliższych

${ }^{1}$ G. Bataille, Historia oka $i$ inne historie, przeł. T. Komendant, Oficyna Literacka, Warszawa 1991, s. 127-128. 
w przekonaniu, że nic tu nie jest udawane oraz że rzeczywiście błądzi w zaświatach. Oto w ślepym spojrzeniu rzucanym przez wywrócone oczy przejawia się sacrum! Obraz oczu, którym światło do niczego nie jest potrzebne, prześladuje autora Historii oka do tego stopnia, że oddzielenie fascynacji wywołanej nimi od przerażenia wydaje się niemożliwe.

Drugim ważnym elementem, który poniekąd stanowi kolejny krok na drodze do zrozumienia Bataille'owksiego zainteresowania ludzkim okiem, jest fotografia chińskiej tortury z kwietnia 1905 roku. Autor Błękitu nieba zdobył ją na trzy lata przed powstaniem Historii oka. Zdjęcie to w owym czasie było podobno bardzo popularne i krążyło po całym Paryżu, nie tylko więc Bataille był w jego posiadaniu. Przedstawiało ono mężczyznę poddanego ćwiartowaniu, któremu odcinano kolejno poszczególne części ciała. Tortura ta zrobiła na Bataille'u tak wielkie wrażenie, przede wszystkim zaś oczy zwrócone w górę, wyglądające jak nie z tego świata, poświadczające ekstazę przeżywającego, iż wyznał nawet, że zdjęcie owo wywarło decydujący wpływ na jego życie.

W tym miejscu pragnę zauważyć, że fascynacja okiem w niemniejszym stopniu opanowała środowisko literatów, co świat artystyczny. André Masson i Hans Bellmer stworzyli ilustracje do Historii oka. W 1928 roku powstał kilkunastominutowy film Luis Benuela oraz Salvadora Dalego Pies andaluzyjski, w którym znajduje się słynna scena rozcinania brzytwą oka. U Hitchcocka w Spellbound z roku 1945 natrafiamy na sekwencję snu, zrealizowaną przez Salvadora Dalego, w której pojawia się niezliczona ilość oczu. Wyłupywanie oka może też stać się źródłem doznań cielesnych, czego przykładem krótkie ujęcie, obecne w produkcji Piera Paolo Pasoliniego z roku 1975: Salo, czyli 120 dni Sodomy. Najbardziej jednak Bataille'owską partię odnajdujemy w Imperium zmysłów Nagisy Oshimy - główny bohater umieszcza jajko w pochwie swojej żony, po czym - kiedy zostaje ono wyjęte - wspólnie z nią je zjada.

\section{BóG, CZYLI SEKS MADAME EDWARDY}

Krótkie opowiadanie wydane w roku 1941, Madame Edwarda, jest jednym z tych nielicznych dzieł Bataille'a, które mówią o Bogu. Poprzedzone przedmową autora i zakończone jego uwagami, mimo to pozostaje opowieścią bardziej bulwersującą, niż kształcącą. W tym miejscu warto może wrócić 
raz jeszcze do Historii oka i przypomnieć jej zakończenie, w którym główny bohater, rozchylając uda swojej przyjaciółki Simony, dostrzega między nimi „jasnoniebieskie oko Marceli”. Utożsamienie oka i kobiecego seksu jest charakterystyczne właśnie dla Bataille’a, a najpełniejszy tego wyraz odnaleźć można właśnie w Madame Edwardzie. Tytułowa bohaterka to zwyczajna prostytutka, choć może nie tak znowu zwyczajna, gdy weźmie się pod uwagę doniosłość jej wypowiedzi. Rozchyla nogi i w tej obscenicznej pozie wyznaje narratorowi: „Jestem BOGIEM” i rozkazuje całować. „Drżałem. Patrzyłem na nią, bez ruchu; uśmiechała się do mnie tak słodko, że drżałem. Wreszcie uklęknąłem, zachwiałem się i złożyłem wargi na tej żywej ranie". Pocałunek ten ma charakter celebracji, jest uroczystym oddaniem Bogu czci. Podobieństwo kobiecego sromu i oka zasadza się przede wszystkim na tym, że jako jedyne organy cielesne nie są one niczym osłonięte, skąd właśnie określenie „żywa rana”. To przez ową „żywą ranę” prześwieca coś w najwyższym stopniu nieokreślonego, co z jednej strony wywołuje obrzydzenie, z drugiej zaś jego przeciwieństwo - oczarowanie, oczarowanie tak wielkie, że porównywalne do spojrzenia Meduzy. Płeć kobieca zostaje przez Bataille'a wywyższona do rangi świętości, a to oznacza gwałtowny zwrot w tradycji filozoficznej.

Problemem, który należy następnie postawić, jest relacja między pojęciem Boga a tym, co autor Doświadczenia wewnętrznego nazywa sacrum. W jego pracach badawczych, np. w Historii erotyzmu, słowo Bóg jest praktycznie nieobecne, w zamian za to aż w nadmiarze występuje określenie o wiele bardziej elastyczne, jakim jest sacrum; choć prawdę mówiąc, oba te terminy są równie niejasne. Za wyczerpującą odpowiedź wolno chyba uznać tę oto zamieszczoną w Przedmowie do cytowanego powyżej opowiadania: „Nie możemy bezkarnie dodawać do języka słowa, które wszystkie słowa przekracza, słowa Bóg; ledwie to uczynimy, słowo to, przekraczające siebie, burzy w zawrotny sposób własne granice"”.

\section{OKO BUDOWNICZYCH LUSTER - MICHEL LEIRIS}

Twórczość Michela Leirisa (1901-1990), choć w ogromniej mierze o charakterze autobiograficznym, za wyjątkiem może Lustra tauromachii,

\footnotetext{
${ }^{2}$ G. Bataille, Madame Edwarda, [w:] Historia oka i inne opowiadania, dz. cyt., s. 49.
} 
jakkolwiek i w nim niektórzy dopatrują się wątków z życia autora, nie stroni jednak od poważnych problemów. Studia etnograficzne zaowocowały przyjaźnią z Bataille'm oraz publikacjami w prowadzonym przez tego ostatniego czasopiśmie Documents. Wiele podróżował, przede wszystkim po krajach Afryki i Azji, czego następstwem były co rusz wydawane kolejne książki; odbywał służbę wojskową w Algierii, był pisarzem, znawcą literatury i poezji, umysłem nadzwyczaj wnikliwym. Nie było chyba rzeczy, która by nie interesowała tego zbieracza wszystkich rzeczy niepotrzebnych, skąd zapewne jego szczególne skłonności do patafizyki.

W Wieku męskim Michela Leirisa czytamy:

Kiedy miałem sześć czy siedem lat, bawiłem się raz karabinem marki Eureka i przez niezdarność posłałem strzał prosto w oko służącej rodziców. Ona zaś (miała na imię Rosa i była chyba dość puszczalska) uciekła wyjąc, że wybiłem jej oko. Przypominam sobie [...] strach i wrzaski, które wydawałem na [tę] myśl. „Wybite oko” nabrało dla mnie bardzo głębokiego znaczenia. Dzisiaj jeszcze mam skłonność, aby żeńskie narządy płciowe uważać za coś brudnego - albo za ranę, która nie przestaje pociągać, ale wydaje się niebezpieczna, jak wszystko co krwawe, oślizłe i skażone ${ }^{3}$.

Już w samym tym wyznaniu nietrudno dostrzec podobieństwo z myślą Georgesa Bataille’a, które najpełniej się wyraża właśnie w skojarzeniu oka i kobiecej płci. Choć w jednej z rozmów autor Lustra tauromachii stwierdza, że „mówienie o erotyzmie pozornie wymaga odwagi, ale w rzeczywistości jest najłatwiejsze", to właśnie jemu, jak się zdaje, poświęca najwięcej miejsca. Noce bez nocy i kilka dni bez dnia - kronika snów, Włókienka, Rupiecie, Skreślenia - swobodne wariacje na różne tematy (ich fragmenty po polsku opublikowała „Literatura na świecie” 5-6 oraz 7-8/2010) oraz Wiek męski dziennik intymny; wszystkie te teksty ociekają erotyzmem, choć w sposób wytrawny. Lustro tauromachii zaś to nadzwyczaj zwięzła analiza fenomenu korridy. Kluczem interpretacyjnym jest jednak erotyzm. Tauromachia, czyli sztuka walki z bykami, nie jest zwykłą sztuką ani tym bardziej sportem. Wzajemnie zharmonizowane gesty matadora i byka, niczym ruchy spółkowania, zmierzają do ostatecznego rozwiązania - śmierci jednej części pary.

${ }^{3}$ M. Leiris, Wiek męski, przeł. T. i J. Błońscy, PIW, Warszawa 1972, s. 67-68. 
Igranie z nią nie jest nigdy celem, o który chodzi zarówno w sporcie, jak i w sztuce - twierdzi Leiris. Balansowanie na granicy życia i śmierci, najlepiej widoczne $\mathrm{w}$ drobnych unikach matadora przez szarżującym bykiem, tzw. pase, dostarcza widzom niebywałych doznań, nieporównywalnych z niczym. Im większe niebezpieczeństwo na arenie, tym głośniejsze owacje i okrzyki tłumu. Toro - figura w najwyższym stopniu falliczna, i torero postać kobieca, która ucieka się do wybiegów, żeby zwabić przeciwnika. Podstęp dokonuje się dzięki purpurowej płachcie, która symbolizuje i barwą przypomina kobiecą płeć. To właśnie nią matador zwodzi byka, by na koniec, w zupełnie niespodziewanym momencie, zadać mu śmiertelny cios. Śmierć zwierzęcia na nowo zaprowadza do życia społecznego porządek, który wcześniej został zachwiany przez złamanie zakazu. Sam torero zaś to nikt inny, jak jeden z tzw. „budowniczych luster” (obok poety i kochanka) są oni tymi, którzy „za sprawą twórczości estetycznej bądź posługując się jakimiś innymi środkami, stają się świadomymi sprawcami naszych objawień"

\section{OKO, KTÓREGO NIE MA - MAURICE BLANCHOT}

Maurice Blanchot (1907-2003) - francuski krytyk i prozaik, chyba największy ze sprzymierzeńców Bataille'a, a zarazem najbardziej spośród nich milczący - wyraża taką oto pochlebną opinię o Madame Edwardzie: „To, że książka najbardziej niestosowna, jak ją określa Georges Bataille w przedmowie, okazuje się w końcu najpiękniejszą, a może i najbardziej czułą książką, jest właśnie absolutnie skandaliczne". Blanchot wydaje się być pisarzem niezwykle trudnym - jego opowiadania przywodzą na myśl atmosferę powieści spod znaku Franza Kafki, równie enigmatycznych, co przygnębiających. Tomasz Mroczny i Szaleństwo dnia to opowiadania ascetyczne aż do przesady, lecz zachowanie formalnej oszczędności wywołuje skutek przeciwny w sferze myśli. Wydaje się zresztą, że to nie myśl rodzi tekst, ale że to tekst wyprowadza myśl na nieznane tory. Nieodpowiedniość języka do rzeczywistości to główny problem gnębiący Blanchota. Może dlatego w Tomaszu Mrocznym akcja najczęściej toczy się nocą, kiedy nic nie widać i kiedy nic nie musi być ostre, jak w świetle dnia. Może się wydawać, że mechanizmem stanowiącym podstawę literatury Blanchota jest gra

\footnotetext{
${ }^{4}$ M. Leiris, Lustro tauromachii, przeł. M. Ochab, Słowo/obraz/terytoria, Gdańsk 1999, s. 51.
} 
przeciwieństw, lecz nic bardziej mylnego - Blanchot raczej jak gdyby przeciąga znaczenie słów aż do absurdu ${ }^{5}$.

Oko w opowiadaniach tego pisarza pojawia się dość często, lecz bardziej niż ono samo narzuca się w nich jego nieobecność. Jest to oko wywrócone na opak, które pochłania mrok, tak jak zazwyczaj światło. Oto najsłynniejszy chyba fragment Tomasza Mrocznego:

\begin{abstract}
Nie widział nic, i daleki od uczucia przygnębienia, ową nieobecność obrazu przetwarzał w kulminację własnego spojrzenia. Jego oko, bezużyteczne, nabierało ogromnych rozmiarów, rozrastało się niepomiernie i rozpościerając się na linii horyzontu, pozwalało wniknąć nocy w sam środek i przyjąć od niej światło. Dzięki tej pustce spojrzenie stapiało się w jedno. oko, które nic nie widziało, nie tylko coś łowiło, ale łowiło też samą przyczynę swojego widzenia. Tomasz widział jako przedmiot, co sprawiało, że nic nie widzi. Jego własne spojrzenie wnikało weń pod postacią obrazu aż do chwili, gdy objawiło się jako śmierć wszelkiego obrazu ${ }^{6}$.
\end{abstract}

Fragment ten wyraźnie przypomina opisy mistycznej ekstazy, w której dochodzi do zaniku granic między podmiotem a przedmiotem i gdzie nie ma już żadnych wizualnych przedstawień. O Bogu Blanchot milczy niemal zupełnie, i to zupełne milczenie może dla jednych być wyrazem

${ }^{5}$ Za najlepszy tego przykład może posłużyć ten oto fragment opowiadania: „W zmarłej Annie nie zabrakło niczego, co było jej właściwe za życia. Każda jej postać była niezbędna, żeby sprowadzić ją do nicości. Raz zazdrosna, raz myśląca, raz porywcza, bez reszty wtrącała Annę w śmierć. W swojej końcówce zdawała się potrzebować większego ładunku istnienia do unicestwienia siebie niż do własnego istnienia i, martwa dzięki temu nadmiarowi, który pozwalał jej się odsłonić bez reszty, urealniała śmierć, nadając jej egzystencję, która stanowiła dowód jej własnej nicości. Nie była nienamacalna ani rozprowadzona $\mathrm{w}$ cieniach, narzucała się zmysłom coraz bardziej. W miarę jak jej śmierć stawała się coraz bardziej rzeczywista, Anna ogromniała, rosła, żłobiła w swoim posłaniu głęboki grób. Ściągała na siebie, ona, tak zatarta, wszystkie spojrzenia. My, stojąc obok, czuliśmy się pomniejszeni przez tę istotę wielkiego formatu. Dusił nas brak powietrza. Teraz każdy z trwogą odkrywał zasadę znaną tylko tragarzom trumien, którzy wiedzą, że zmarli ważą dwukrotnie więcej, że są spośród wszystkich bytów najpotężniejsi, najsilniejsi. [...] Potem zostałem przy niej sam. Była bez wątpienia martwa w chwili, kiedy można było sądzić, że zyskuje nade mną przewagę. Posłużyła się śmiercią niczym wybiegiem": M. Blanchot, Tomasz Mroczny. Szaleństwo dnia, przeł. A. Wasilewska, A. Sosnowski, Biuro Literackie, Wrocław 2009, s. 60.

${ }^{6}$ M. Blanchot, dz. cyt., s. 13-14. 
praktykowania przez niego radykalnej teologii negatywnej, dla innych zaś czymś zupełnie obojętnym, czego braku podczas lektury nawet nie odczuwają, a dla jeszcze innych - potwierdzeniem ateizmu. Tomasz Mroczny i Szaleństwo dnia nie rozwiązują żadnego problemu, ale nie takie jest ich zadanie. One zresztą nie mają spełniać żadnego zadania - są tylko szansą, zgodnie z powiedzeniem, że „każda książka mieści w sobie nieskończoną ilość możliwości”.

\section{ZAKOŃCZENIE}

Na przestrzeni historii filozofii o oku mówiono na wiele sposobów i różne intencje się w tej mowie kryły - traktowano je mniej bądź bardziej dosłownie jako organ umożliwiający widzenie, jako figurę symboliczną, metaforę czegoś, wewnętrzne oko umysłu, jako synonim naoczności bądź też samą zdolność widzenia, patrzenia, oglądania, powierzchownego badania oraz jako strukturę samego procesu postrzegania. Na koniec zaś, a co już jest domeną Bataille'a i jemu podobnych, oku przyznano autonomię, wyizolowano je z właściwego mu otoczenia, wobec czego przestało ono być jedynie narzędziem, a stało się żywym obiektem, wobec którego żywiono już to głęboką nienawiść, już to darzono uwielbieniem. Wzięto je więc w najbardziej dosłownym sensie: jako błyszczącą krągłość osadzoną w ciele, do ciała niejako przywiązaną. Na długo przed pojawieniem się prawdziwej krytyki feministycznej, problem logocentryzmu i okulocentryzmu w filozofii (lecz nie tylko) został podjęty przez myśl francuską związaną z kręgiem skupionym wokół André Massona. Byli to przede wszystkim mężczyźni, z jednym wyjątkiem Colette Peignot. Zatem można powiedzieć - a chyba nie będzie to nadużyciem - że i w tej dziedzinie mężczyźni okazali się lepsi od kobiet. 